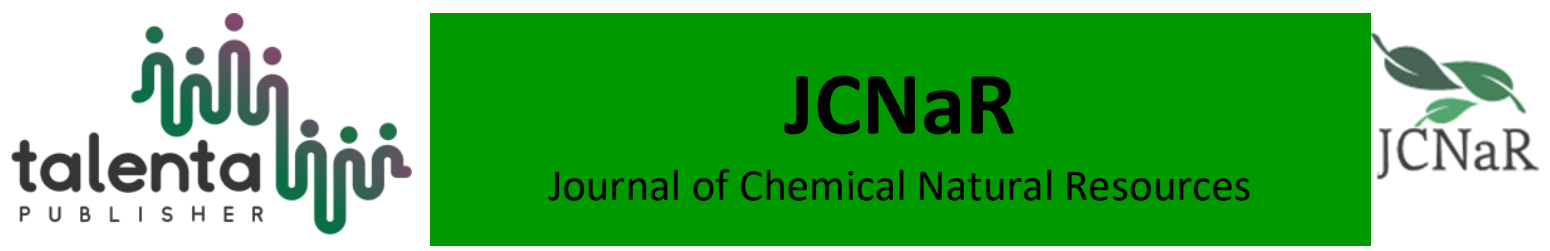

\title{
The Surface Coverage and Corrosive Rate of Methanol Extract from Taro Tuber (Colocasia esculenta) on Mild Steel in Sulfuric Acid
}

\author{
Diah Riski Gusti ${ }^{*}$, Haryanto ${ }^{2}$, Nofrizal Jhon ${ }^{3}$ \\ ${ }^{1,3}$ Department of Chemistry, Faculty of Science and Technology, Universitas Jambi, Kampus Pinang \\ Masak, Jalan Lintas Jambi- Ma. Bulian Km 15, Jambi Luar Kota, Muaro Jambi Regency, Jambi, \\ Indonesia, 36361 \\ ${ }^{2}$ Department of Chemistry Education, Faculty of Keguruan dan Education, Universitas Jambi, Kampus \\ Pinang Masak, Jalan Lintas Jambi- Ma. Bulian Km 15, Jambi Luar Kota, Muaro Jambi Regency, Jambi, \\ Indonesia, 36361
}

\begin{abstract}
Surface coverage and corrosion rate of taro tuber methanol extract on mild steel in dilute $0.5 \mathrm{M}$ sulfuric acid solution were studied through weight loss method, FT-IR spectroscopy and SEM.The result obtained in $0.5 \mathrm{M}$ sulfuric acid solution for 72 hours with optimal surface coveragewas 0.86 . The corrosion ratewas found to be decreased and surface coveragewas increased with the increasing concentration of taro tuber methanol extract which was added. The results showed that taro tuber methanol extract was a good corrosion inhibitor.
\end{abstract}

Keyword: inhibitor, corrosion, Taro, sulfuric acid

Received 30 July 2019 | Revised 26 August 2019| Accepted 29 August 2019

\section{Introduction}

Taro, Colocasiaesculenta (L.), Schott, is categorized asAraceae family, which is widely consumed as staple food by many countries and easy to grow in tropical and subtropical countries such as Indonesia and other Southeast Asian countries (Kumoro et al, 2013, MunozCuervo et al, 2016). Most taro cultivars taste acrid and can cause swelling of lips, mouth and throat if they are eaten raw (Bradbury, et al 1998 ). Taro plants (Colocasia esculenta) is also a cultivated plants that are used as an alternative food ingredient. However, one of the obstacles of this plant being used as food is in the roots of itching caused by the presence of oxalate compounds (Kumoro et al, 2013). Taro also contains phenolic compounds and carotenoids (Munoz-Cuervo et al, 2016). In addition, the presence of oxalate in foods has also been implicated in reducing the bioavailability of essential minerals such as calcium (Paull, et al , 1999, Kelsav, 1985 ).

\footnotetext{
*Corresponding author at: Department of Chemistry, Faculty of Science and Technology, Universitas Jambi, Jambi, Indonesia

E-mail address: diahgusti07@yahoo.co.id
} 
Gusti (2008) and Gusti (2009) reported that succinic acid and pure oxalic acid are able to inhibit the corrosion rate of steel in sulfuric acid. Taro tubers containing oxalate compounds are included asdicarboxylic compounds that can chelate metals so that they are expected to be used as metal corrosion inhibitors. Compounds containing heteroatom such as $\mathrm{N}, \mathrm{O}, \mathrm{P}, \mathrm{S}$ and double bonds can be used as corrosion inhibitors (Gusti et al, 2015).

Corrosion is a chemical process which can reduce the quality of metals. The use of corrosion inhibitor is one of the most effec- tive measures for protecting metal surfaces against corro- sion in acid environments (Sherbini, 1999). Some organic compounds are found to be effective corrosion inhibitors for many met- als and alloys. Generally, inhibitor molecules may physically or chemically adsorb on a corroding metal surface. In any case, adsorption is generally over the metal surface forming an adsorption layer that functions as a barrier protecting the metal from the corrosion (Elayyachy, et al , 2005, Bouklah, et al 2006)Therefore, to use corrosion inhibitor is one way of decreasing the corrosion process rate. To sum up, it is necessary to examine the ability of methanol extract from taro to inhibit metals. In this research, the metal used was steel in sulfuric acid solution as a corrosive medium.

\section{Materials And Method}

\subsection{Steel Surface Preparation}

Steel with a diameter of $\pm 2.4 \mathrm{~cm}$ was smoothed with sandpaper. The smooth surface was washed with distilled water and acetone then dried in oven at $400{ }^{\circ} \mathrm{C}$ for 5 minutes.

\subsection{The Preparation of Taro Extract}

Taro leaf tubers were dried and cutted into small pieces and then dried. The sample was then blended with a blender so that it is in the form of powder. An amount of $1.3 \mathrm{~kg}$ Taro tuber powder was macerated with methanol solvent for 3 days. The mixture was filtered and the filtrate was taken. The pulp or residue from taro tuber powder was re-extracted up to six times and the filter was mixed with the first filtrate. The filtrate was evaporated using rotary evaporator until a concentrated extract was obtained. Finally, the concentrated extract was dried.

\subsection{The Preparation of Corrosive Medium Solution}

The corrosive medium solution of $1 \mathrm{M}$ sulfuric acid was made from concentrated sulfuric acid by diluting $27.6 \mathrm{ml}$ of concentrated sulfuric acid in a $500 \mathrm{ml}$ volumetric flask to the boundary mark. Then the concentration of sulfuric acid was diluted to $0.5 \mathrm{M}$ with the formula $\mathrm{M}_{1} \mathrm{~V}_{1}=\mathrm{M}_{2} \mathrm{~V}_{2}$.

\subsection{The Preparation of Inhibitor Solution}

In this research, the inhibitor solution was a concentrated extract of $1000 \mathrm{ppm}$ made by dissolving 1 gram of methanol extract from concentrated taro into a measuring flask with sulfuric acid solution up to the boundary mark. The desired inhibitor solution was made by 
diluting a 1000 ppm solution of concentrated extract in stages of 100, 200, 300, 400, 500, 600, 700,800 and 900 ppm respectively.

\subsection{The Soaking Process of Mild Steel in Corrosive Medium Solution with or without Inhibitorand The Determination of Corrosive Rate and Surface Coverage}

The prepared steel samples were immersed in sulfuric acid solution with the extract of tuber and taro leaves. The concentrations of tuber and leaf stalks were concentrated into 0, 100, 200, 300, 400, 500, 600, 700, 800 and $900 \mathrm{ppm}$ with solvents of $0.5 \mathrm{M}$ sulfuric acid respectively. From each concentration, a volume of $50 \mathrm{ml}$ was taken and putted in a glass with a steel position suspended with the rope for 0 - 24 hours, 0 - 48 hours, 0 - 72 hours. Finally, the corrosion rate and surface coverage were then measured.

$$
\begin{gathered}
\text { Corrosion Rate }(\boldsymbol{C R})=\frac{\text { Initial Weight }- \text { Final Weight }}{\text { Steel Areax Soaking Time }} \\
\theta=\frac{C_{R(\text { blank })-C_{R(\text { inh })}}}{\left.C_{R(\text { blan })}\right)}
\end{gathered}
$$

$C_{R}$, corrosion rate, $\theta$, surface coverage, $C_{R(B l a n k)}$, corrosion rate without inhibitor and $C_{R(\text { Inh) }}$, corrosion rate with inhibitor.

\subsection{FTIR Analysis}

The FTIR analysis was conducted on methanol extract samples of taro tuber and surface layer on steel after soaking process for three days in a $0.5 \mathrm{M}$ sulphuric acid solution. The layer formed on the surface of the steel was taken and dried. After dried, it was mixed with $\mathrm{KBr}$, crushed until smooth, then analyzed using Perkin Elmer System 2000 Fourier Transform Infra Red Spectroscopy (FT-IR).

\subsection{Scanning Electron Microscopy (SEM)/ Electron Dispersi X-Ray (EDX) Analysis}

SEM and EDX analysis were performed on steel soaked in $0.5 \mathrm{M}$ sulphuric acid solution without and with the addition of methanol extract of taro tuber for 72 hours.After 72 hours, the mild steel was washed with distilled water and then rinsed with acetone. Finally, the steel was dried and its surface morphology was analyzed using Hitachi S3400N SEM / EDX with EMAX Software.

\section{Result and Discussion}

\subsection{The Corrosion Rate and Surface Coverage Analysis}

The weight loss method was used to determine the corrosion rate and the surface coverage of mild steel in a $0.5 \mathrm{M}$ sulfuric acid solution containing the methanol extract of taro tuber. The determination of corrosion rate and surface coverage using the weight loss method uses equations 1 and 2. Figure 1a shows the effect of the concentration of methanol extract from taro 
tuber on the corrosion rate while Figure $1 \mathrm{~b}$ reveals the effect of the concentration of each extract on surface coverage.

The corrosion rate on the addition of methanol extract from taro displayed Figure 1a is lower and the surface coverage in Figure $1 \mathrm{~b}$ is greater than without the addition of methanol extract of taro tubers. The addition of methanol extract of taro tubers results the formation of a protective layer by the compounds contained in the extract. Moreover, it is covering the surface of steel so that it inhibits aggressive ion attacks from acidic solutions(Ciceket al, 2011, Gusti, 2017, Sangeethaaet al, 2016).

The corrosion rate decreases and the surface coverage increases with increasing concentration of methanol extract of taro tubers shown in Figure 1a and Figure 1b. In the increasing of concentration, the compounds contained in the methanol extract of taro tubers are increasingly adsorbed on the surface of mild steel. The compounds of methanol extract of taro tubers form a thin layer through Oxygenatoms which have free electron pairs on $\mathrm{OH}$ groups and are adsorbed on the surface of soft steel. The layer covers and protects the mild steel surface from the attack of corrosive ions in acid solution which results in the dissolution of iron to the solution decreases, so that the corrosion rate decreases and the surface coverage increases (Abdallah $e t$ al, 2012, Sangeethaaet al, 2016, Yetriet al, 2015 and Zakariaet al, 2016).

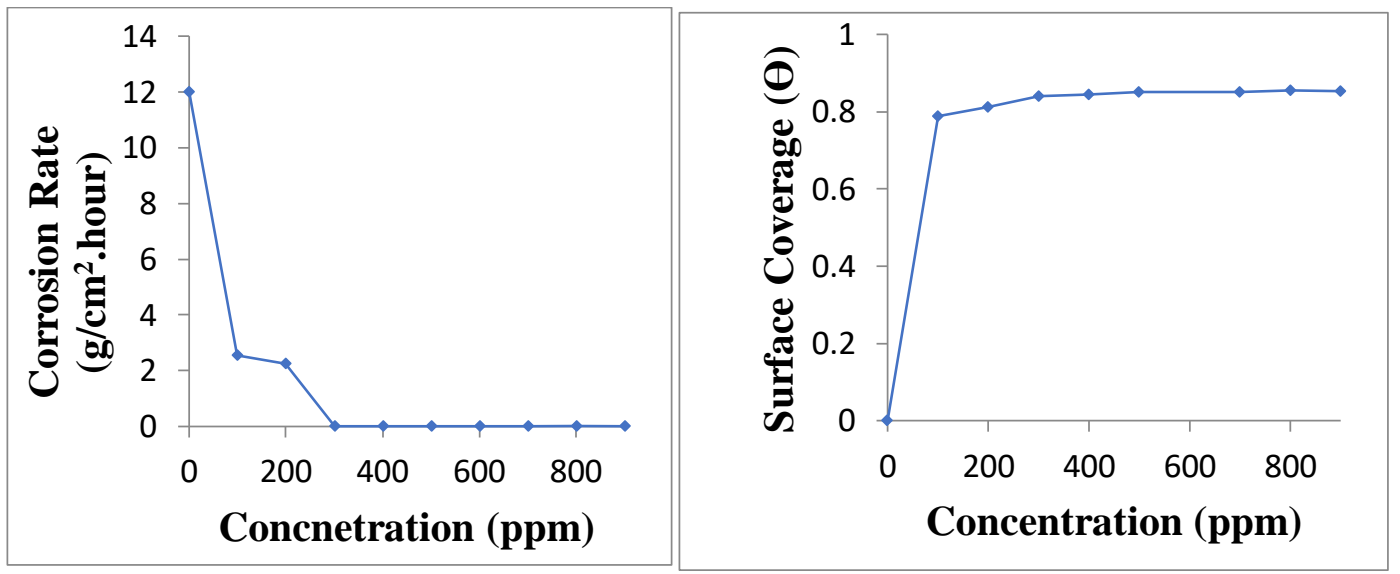

$\mathbf{a}$

Figure 1. The graph of (a) methanol extract from taro tuber and corrosion rate relationship and (b) methanol extract from taro tuber and surface coverage

\subsection{FTIR Analysis}

The Fourier Transform Infra Red (FTIR) analysis was used to identify functional groups that act as corrosion inhibitors of compounds contained in methanol extract from taro tubers. The results of the FT-IR spectrum shown in Figures 2 and 3 show differences in spectrum patterns. The significant differences were observed from the description of FTIR spectrum between the compounds of methanol extract from taro tubers and surface coating products on mild steel 
which had been soaked for three days in a $0.5 \mathrm{M}$ sulphuric acid solution. This difference indicates that an interaction of $\mathrm{Fe}^{2+}$ on the mild steel surface has occurred

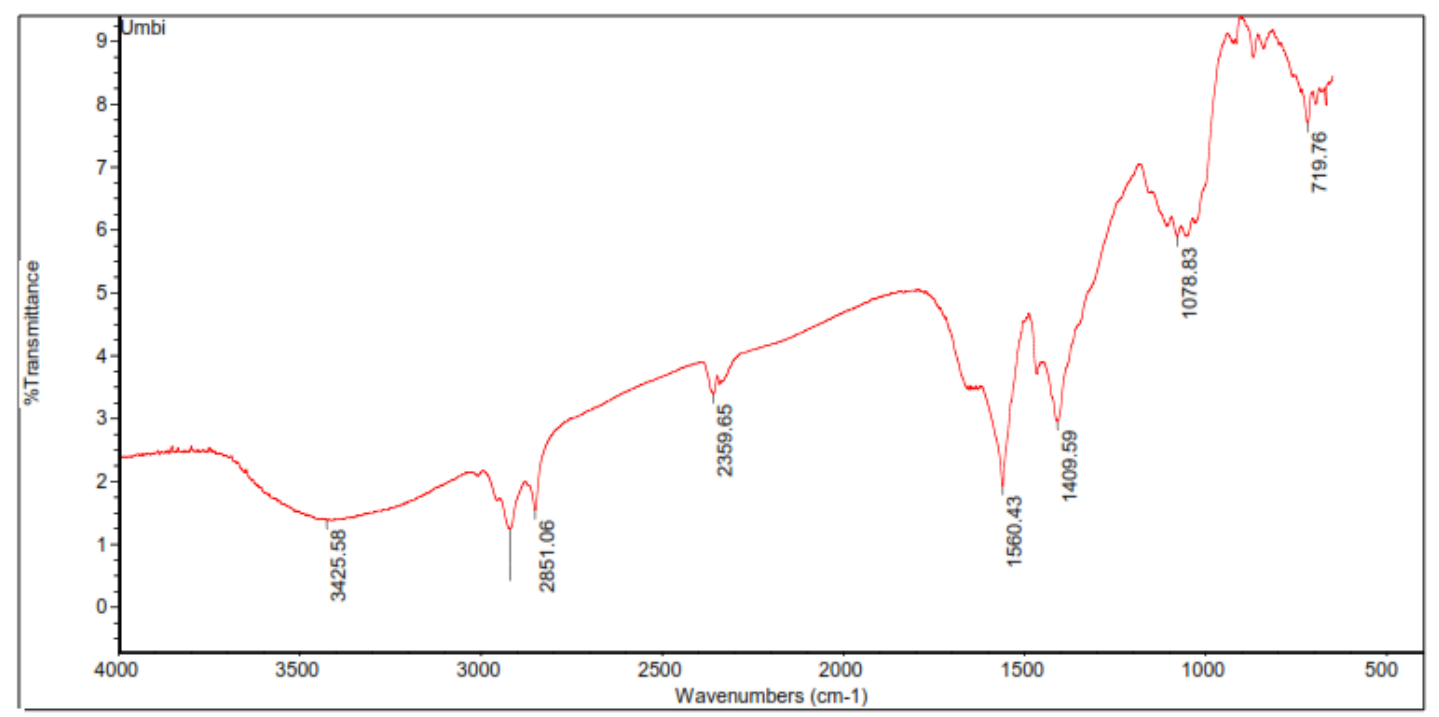

Figure 2. The FTIR spectrum of methanol extract from taro tuber (Colocasia Esculenta)

Figure 2 shows that the absorption band at $3425 \mathrm{~cm}^{-1}$ corresponds to the presence of $\mathrm{OH}$ functional groups. Then, absorption band at $2851.06 \mathrm{~cm}-{ }^{1}$ indicates the $-\mathrm{CH}$ absorption. The uptake of the $\mathrm{C}=\mathrm{C}$ double bond is shown at wave number of $1560.43 \mathrm{~cm}^{-1}$. The $\mathrm{OH}$ group is shown by the wave number of $1409.59 \mathrm{~cm}^{-1}$. Also, wave number of $1078 \mathrm{~cm}^{-1}$ is a C-O strain. From this spectrum image, it can be seen that taro tuber extract has $\mathrm{OH}$ functional groups.

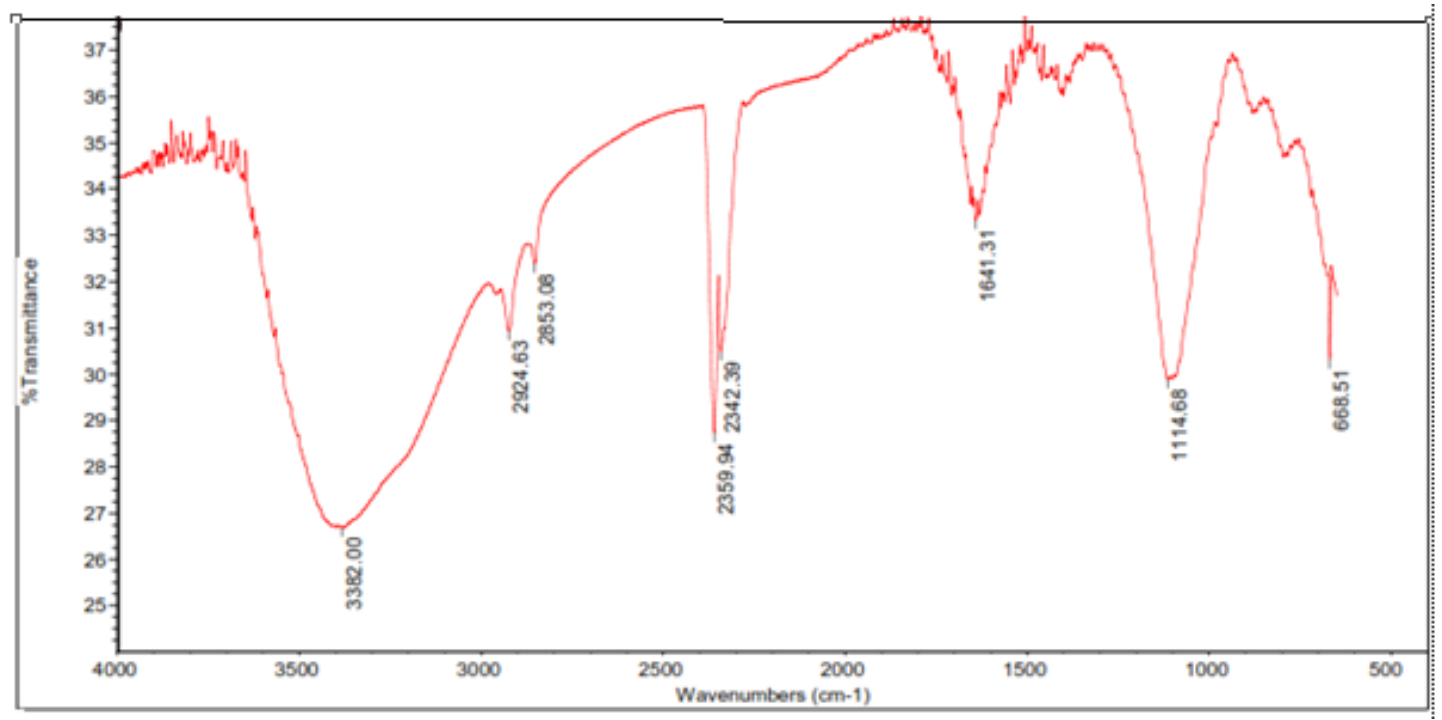

Figure 3.The FTIR spectrum of mild steel surface layer

Based on figure 3, it can be seen that there is a change in the FT IR spectrum of the product in the steel surface layer after being immersed for three days in a $0.5 \mathrm{M}$ sulfuric acid solution with the presence of methanol extract from taro tuber with a concentration of $900 \mathrm{ppm}$. The absorption band at $3382 \mathrm{~cm}^{-1}$ showed $\mathrm{OH}$ stretching with the shift of $\mathrm{OH}$ group in taro tuber extract from $3425.8 \mathrm{~cm}^{-1}$ to $3382 \mathrm{~cm}^{-1}$. The C-O shift occurs at the peak of $1114.68 \mathrm{~cm}^{-1}$, indicating a $\mathrm{C}-\mathrm{O}$ strain. The shift of wave numbers shows the interaction of groups from 
extracts with steel surfaces. Moreover, there are a group of extracts whose peaks are no longer visible, namely the peak at $1409.59 \mathrm{~cm}^{-1}$ which indicates an $\mathrm{OH}$ bond.

\subsection{The Steel Surface Analaysis with Scanning Electrone Microscopy (SEM)}

Scanning Electron Microscopy (SEM) analysis provides information on steel surface morphology. Figure 5 shows the difference in steel surface shape before treatment and after immersion in sulfuric acid solution with and without the addition of methanol extract for 3 days with 500x magnification.

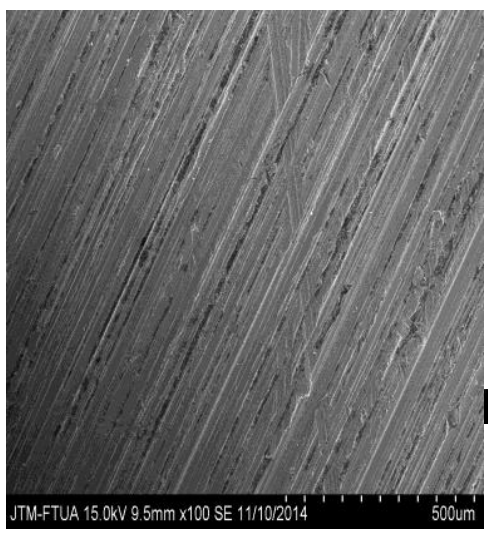

$a$

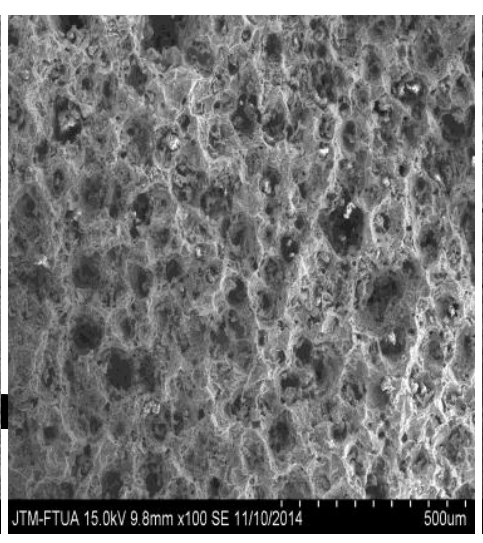

$b$

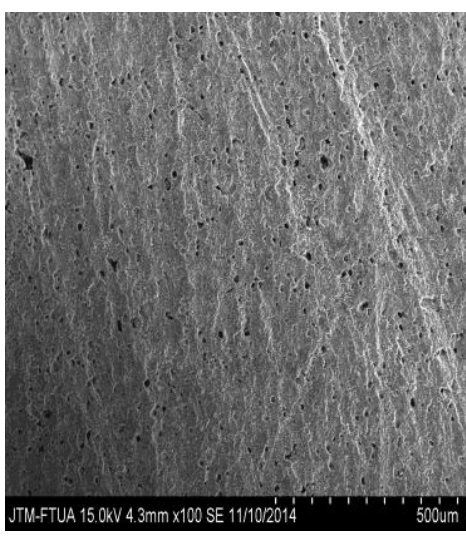

C

Figure 4.The surface steel condition of (a) before treatment, (b) soaked in sulfuric acid (c) soaked in sulfuric acid + methanol extract of taro tuber

Figure 4 shows that the steel surface after being immersed in sulfuric acid has been corroded where there are pores on the steel surface. Whereas on the surface of steel which has been immersed in sulfuric acid which has been added with methanol extract of taro tuber, the steel surface is finer than the steel surface soaked with sulfuric acid. This is due to the chemical compounds found in the crude extract of taro tubers adsorbed on the steel surface and coat the surface to slow the occurrence of corrosion (Fiory-Bimbi et al, 2015, Gusti et al, 2017).

\section{Conclusion}

The corrosion rate of mild steel soaked in sulfuric acid without the presence of methanol extract from taro tuber was greater than in sulfuric acid with the addition of methanol extract of taro tuber.The surface coverage in soft steel soaked in sulfuric acid without the methanol extract of taro tuber was smaller than in sulfuric acid with the addition of methanol extract of taro tuber.The degree of mildsteel surface coverage by methanol extract of taro tuber reached 0.86 . Finally, it can concluded that methanol extract of taro tuber is a good and environmentally friendly corrosion inhibitor.

\section{References}

[1] Abdallah, M., Zaafarany, I.,Khairou, K.S and M.Sobhi. 2012.Inhibition of Carbon Steel Corrosion by Iron(III) and Imidazole in Sulfuric Acid.Int. J. Electrochem. Sci.7:1564 1579 . 
[2] Bouklah M., Hammouti B., Lagrene'e M., Bentiss F., 2006. Thermodynamic properties of 2,5-bis(4-methoxyphenyl)-1,3,4-oxadiazole as a corrosion inhibitor for mild steel in normal sulfuric acid medium, Corros. Sci. 48 2831-2842.

[3] Bradbury JH, Nixon R. 1998. The Acridity of Raphides from the Edible Aroids, J Sci Food Agric ; 76: 608-618.

[4] Cicek, V., and B. Al-Nunman. 2011. Corrosion Chemistry. Schrivene.Publishing. Salem. Canada. pp. 1-4

[5] Elayyachy M, Hammouti B., Idrissi A., 2005, New telechelic com- pounds as corrosion inhibitors for steel in $1 \mathrm{M} \mathrm{HCl}$, Appl. Surf. Sci. 249 pp. 176-182.

[6] Fiori-Bimbi., M.V., P.A. Alvarez., H. Vaca., and C.A. Gervazi. 2015. Corrosion Inhibition of Mild Steel in HCl Solution by Pectin, Corr. Sci.92, 192- 199.

[7] Gusti, D.R., Emriadi, Alif, A., dan M. Efdi. 2015. "Water Extracts of Cassava Leaf as Corrosion Inhibitor for Mild Steel in Sulfuric Acid Solution”. Journal of Chemical and Pharmaceutical Research. 7(12): 398-405.

[8] Gusti, D.R., Emriadi, Alif, A., dan M. Efdi. 2016. "Surface Characteristic on Mild Steel Using Aqueous Extract of Cassava (Manihot esculenta) Leaves as a Corrosion Inhibitor". Der Pharma Chemica. 8(17): 113-118.

[9] Gusti, D.R., Emriadi, Alif, A., dan M. Efdi. 2017. "Corrosion Inhibition of Ethanol Extract of Cassava (Manihot esculenta) Leaves on Mild Steel Ni Sulfuric Acid". International Journal of ChemTech Research. 10(2): 163-171.

[10] Gusti, D.R., Aritonang, H.F., dan S. Aziz. 2008 Pengaruh Penambahan Asam Suksinat Dalam Menghambat Korosi Baja Dalam Larutan Asam Sulfat. Chemistry Progress.Volume 1. No 1 Jurusan Kimia Fakultas Matematika dan Ilmu Pengetahuan Alam Universitas Sam Ratulangi.

[11] Gusti, D.R.2009. Laju Korosi Dalam Larutan Asam Sulfat Dengan Menggunakan Inhibitor Asam Oksalat. Chemistry Progress.Volume 1. No 2 Jurusan Kimia Fakultas Matematika dan Ilmu Pengetahuan Alam Universitas Sam Ratulangi.

[12] Gusti, D.R., Farid, F., dan I. Lestari. 2013. "Ekstrak Kulit Kayu Akasia sebagai Inhibitor pada Laju Korosi Baja Lunak dalam Media Asam Sulfat". Prosiding Semmirata FMIPA Universitas Lampung. Lampung: Universitas Lampung.

[13] Kelsav JL.1985. Effect of oxalic acid on calcium bioavailability. In Kies C, editor. Nutritional Bioavailability of Calcium. Washington DC: American Chemical Society;. p. $105-116$.

[14] Kumoro, A.C., Putri, R.D.A., and Budiyati, C.S.,2014. Kinetics of Calcium Oxalate Reduction in Taro (Colocasia esculenta) Corm Chips during Treatments Using Baking Soda Solution, International Conference and Workshop on Chemical Engineering UNPAR 2013, ICCE UNPAR. Procedia Chemistry $9102-112$.

[15] Muñoz-Cuervo, I., Malapa, R., Michalet, S.,Lebot, V., Legendre, L. 2016. Secondary metabolitediversity in taro, Colocasia esculenta(L.)Schott.Corms. Journal of Food Composition and Analysis. 52. 24-32.

[16] Paull R, Tang C, Gross K, Uruu G. 1999. The nature of the acridity factor. Posthar Biol Technol ; 16: 71-78

[17] Sherbini, E, 1999., Effect of some ethoxylated fatty acids on the corrosion behaviour of mild steel in sulphuric acid solution, Mater. Chem. Phys. 60 pp. 286-290

[18] Sangeethaa, Y.,S. Meenakshia., C.S. Sundaram. 2016. Interactions at the mild steel acid solution interface in the presence ofO-fumaryl-chitosan: Electrochemical and surface studies.Carbohydrate Polymers. 136: 38-45 
[19] Yetri, Y., Emriadi, N. Jamarun., and Gunawarman. 2015.Corrosion inhibitor of mild steel by polar extract of Theobroma cacao peels in hydrochloric acid solution. Asian Journal of Chemistry. 27.(3): 875-880

[20] Zakaria, K., A. Hamdy., M.A. Abbas., O.M. Abo-Elenien., 2016, New organic compounds based on siloxane moiety as corrosion inhibitors for carbon steel in $\mathrm{HCl}$ solution: Weight loss, electrochemical and surface studies, J. of the Taiwan Instof Chem Eng.1-14. 